\title{
Effects of Leadtree Seed (Leucaena leucocephala) Extract in Inhibiting the Increase of Postprandial Blood Glucose Level in Alloxan-induced Diabetic Rats
}

\author{
Ibnu Wadud Pujangga ${ }^{1 *}$, Dorlina Nainggolan ${ }^{2}$, Maria Selvester Thadeus ${ }^{3}$ \\ ${ }^{1}$ Bachelor Study Program of Medical Science, UPN Veteran Jakarta, Jakarta 12450, Indonesia \\ ${ }^{2}$ Department of Pharmacology, Faculty of Medicine, UPN Veteran Jakarta, Jakarta 12450, Indonesia \\ ${ }^{3}$ Department of Anatomical Pathology, Faculty of Medicine, UPN Veteran Jakarta, Jakarta 12450, Indonesia
}

\begin{abstract}
This research aimed to add evidence on the effect of white leadtree seed extract (Leucaena leucocephala) on postprandial blood glucose level on white male alloxan induced diabetic rats. This research was an experiment with pretest-posttest control group design. The subjects of this research were 25 white male rats, Wistar strain was divided into 5 groups. Group I was the positive control, which was treated with Acarbose, group II was the negative control, and group III, group IV, and group V were treatment groups and were given white leadtree seed extract of $1.5 \mathrm{~g} / \mathrm{kg}$ of BW, $3.5 \mathrm{~g} / \mathrm{kg}$ of BW, and $7.8 \mathrm{~g} / \mathrm{kg}$ of BW respectively. Blood glucose level was checked before and two hours after treatment. The statistical analysis used one-way ANOVA and Bonferroni post hoc test. The result showed that there were no significant differences between group III, group IV, and group V and the positive control group $(p<0.05)$. The best result of inhibition of the increase in blood glucose level was found in $7.8 \mathrm{~g} / \mathrm{kg}$ of BW (group V) dosage group with average difference of $186.4 \mathrm{mg} / \mathrm{dl}$. In conclusion, white leadtree seed extract could decrease two hour postprandial blood glucose level in white male alloxan-induced diabetic rats and a dosage of $7.8 \mathrm{~g} / \mathrm{kg}$ of BW was shown to be the most effective.
\end{abstract}

Keywords: diabetes mellitus, two hour postprandial blood glucose level, white leadtree seed extract

\section{INTRODUCTION}

Postprandial hyperglycemia still remained a problem in management of type 2 Diabetes Mellitus (DM) (Fonseca 2003). Postprandial hyperglycemia is marked by a rapid and high increase in blood glucose concentration. In the postprandial phase, there is a possibility of a hyperglycemic surge (Ceriello 2005). This surge phenomenon might induce the endothelial dysfunction, inflammatory reaction, and oxidative stress that could cause organ failure (Node \& Inoe 2009). Thus, postprandial hyperglycemia management is pivotal for the treatment of DM type 2 (Dijk et al. 2011).

In general, oral hypoglycemic drugs or insulin injections aim to regulate the blood glucose concentration. However, this effort had not been able to fully prevent the occurrence of complications. In addition, the price of synthetic drugs is quite expensive and therefore, alternative drugs are developed (Jasaputra et al. 2014). Of all anti-diabetic drugs available, $\alpha$-glucosidase inhibitor seems to be the most effective in reducing the postprandial hyperglycemia (Derosa
$\&$ Maffioli 2012). The excellence of $\alpha$-glucosidase inhibitor over other drugs is that it has not caused hypoglycemia. One of $\alpha$-glucosidase inhibitors that are commonly used is acarbose (Ndraha 2014).

One of the traditional medical plants used by Indonesian in treating diabetes is the white leadtree (Lucaena leucochepala) (Kuppusamy et al. 2014). White leadtree is a shrub plant, containing active substance such as flavonoids, galactomannan, tannin, calcium, phosphorus, and iron, as well as vitamin $\mathrm{B} 1$, vitamin $\mathrm{C}$, and vitamin $\mathrm{A}$. The content of flavonoids, tannins, and galactomannan in white leadtree could inhibit the increasing of blood glucose concentration, by inhibiting the activity of $\alpha$-glucosidase which played role in the process of glucose absoption in brush border cell membrane in small intestine (Silvita 2015).

As a metabolic disorder, the prevalence of Diabetes Mellitus (DM) had increased from around 108 million in 1980 to 422 million in 2014. The increase in prevalence of type $2 \mathrm{DM}$ patients is higher in the middle and low income countries (WHO 2016). International Diabetes

\footnotetext{
"Corresponding Author: tel: +6285711674423, email: pujanggaibnu@gmail.com
} 
Federation (IDF 2011) stated that more than 371 million people have DM, 4.8 million people die because of this metabolic disease and 471 billion US dollar was spent for the treatment.

In Indonesia, DM prevalence had increased from 1.1 percent in 2017 to 2.1 percent in 2013. The highest prevalence of DM that was diagnosed by clinicians is in DI Yogyakarta $(2.6 \%)$, DKI Jakarta (2.5\%), North Sulawesi (2.4\%), and East Kalimantan (2.3\%) (Balitbangkes 2013). DM is serious public health threat, since it might cause various disability, such as blindness, kidney failure, diabetic feet, heart disease, and stroke (Depkes RI 2013).

Various research have been conducted on the role of white leadtree in reducing blood glucose concentration. Silvita et al. (2015) stated that the infusion of white leadtree reduced the blood glucose concentration in diabetic mice model. This study used acarbose as positive control, but it used infusion method. Therefore, the active substances produced by white leadtree were unstable and easily polluted.

Other study by Nugraha and Yusuf (2015) suggested that the use of ethanol extract of white leadtree reduced fasting blood glucose concentration and the level of pancreatic $\beta$-cells damage in hyperglycemic rats induced by alloxan. Hypoglycemic ethyl acetate fraction derived from white leadtree was able to reduce the concentration of glucose in wistar rats induced by alloxan. That study used glibenclamide as the positive control, in which its mechanism was to increase insulin and unlike acarbose that inhibits the absorption of glucose in gastrointestinal tract. On the other hand, the study by Utami et al. (2015) showed that white leadtree had no effect in reducing the concentration of blood glucose in wistar rats induced by alloxan. That study used insulin as its positive control. Insulin worked directly in blood and therefore, the inhibition of increasing two hour postprandial blood glucose level could not be seen.

Mice and humans had similar metabolism and thus, mice were often used as experimental animals (Febrian 2017). Alloxan was used in this study because of its cytotoxic characteristic to pancreatic $\beta$-cell through the formation of free radicals and oxidative stress. Alloxan induced the release of calcium ions from mitochondria so that the process of cell oxidation was disrupted. The release of calcium ion from mitochondria caused homeostatic disorder, which was the beginning of cell death. Alloxans' mechanism in damaging pancreatic $\beta$-cells resulted in the decrease of insulin concentration and disruption of blood glucose homeostasis so that blood glucose increased (Akrom et al. 2014).

Based on the scientific information above, there is a need to investigate whether the white leadtree (Leucaena leucocephala) have any effect to inhibit the increase of two hour postprandial blood glucose concentration in white male diabetic rats, induced by alloxan.

\section{METHODS}

\section{Design, location, and time}

This study is a true-experiment with pretestposttest control group design. This study was conducted in the Department of Pharmacology and Therapy, Faculty of Medicine, Padjajaran University, Bandung. The making of white leadtree extract was carried out in Balai Penelitian Tanaman Rempah dan Obat (BALITRO), Bogor. This study was conducted in September 2016 until August 2017.

\section{Sampling}

The sample size of each group was calculated using Federer with $\mathrm{n}$ as number of sample, and $t$ as number of group. The following was the formula used,

$$
(\mathrm{n}-1)(\mathrm{t}-1) \geq 15
$$

Based on Federer's formula, the sample needed for each group was 5 white male rats. To avoid the reduction of samples' due to death during the treatment, 2 more white rats were added in each group (drop out), so the number of sample for each group was 7 rats and thus, counting for 35 white male rats in total. This research has received ethical approval from Ethics Committee of Faculty of Medicine UPN Veteran Jakarta No: B/1185/IX/2017/KEPK.

\section{Materials and tools}

The instruments used were experimental animal cages along with feeding and drinking supplies, animal and digital scales, disposable syringe, glucose strip test Easy Touch ${ }^{\circledR}$, cotton, alcohol, scissors, knives, rat stomach, rat oral gavage, mortar, measuring cup. The ingredients used were $70 \%$ ethanol extract of white leadtree, acarbose, sucrose, $0.5 \%$ carboxymethyl cellulose (CMC), alloxan monohydrate, sucrose, and $0.9 \%$ physiological solution of $\mathrm{NaCl}$. The experimental animals used in this study were 35 white male wistar rats with sex of male, aged 2-3 months, and weight of 200-250 g the inclusion criteria. 


\section{Procedures}

Mice were acclimatized in the cage for 7 days, one cage for each mouse. The mice were then given standard food in pellets and drinks in ad libitum. Rat food was provided at night since rats are nocturnal animals that actively eat at night.

On day 8 , all rats were weighed and fasted for 8 hours, furthermore their Fasting Blood Sugar (FBS) level were examined. FBS and weight examinations were to ensure that rats used in this study matched the inclusion criteria and were feasible as experimental animals. The examinations were also to determine alloxan doses. Alloxan acts by damaging the essential substances in pancreatic $\beta$-cells, causing the reduction of granules in pancreatic the cells (Yuriska 2009). Alloxan with a dose of $125 \mathrm{mg} /$ $\mathrm{kg}$ of BW was prepared by dissolving $875 \mathrm{mg}$ of alloxan in $35 \mathrm{ml} \mathrm{NaCl}$, thus $25 \mathrm{mg} / \mathrm{ml}$ suspension was obtained. Once the alloxan was ready, alloxan was injected intra-peritoneally based on the doses. The effect would appear for \pm 3 days while being fed and given drink as usual.

Alloxan that was induced to make normal rats became diabetic had a success rate of $\pm 8 \%$. If diabetic effect did not appear in 5 days after injection, re-injection was done (Efendi et al. 2010). Furthermore, the rats were fed with feed pellets and given drink in ad libitum until the day 10.

Day 11 was 3 days post induction of alloxan, every rats was fasted for 8 hours. On day 12 , or 4 days post induction of alloxan, FBS concentration examination was conducted. Blood sugar concentration $<126 \mathrm{mg} / \mathrm{dl}$ was excluded from this study, and the subject of the study was randomized.

Group I as positive control (acarbose + sucrose). Acarbose inhibits the increasing of postprandial blood glucose concentration. Group II as negative control ( $0.5 \% \mathrm{CMC}+$ sucrose). $0.5 \%$ CMC had no effect in inhibits the increasing of post prandial blood glucose concentration. Group III was white leadtree extract $1.5 \mathrm{~g} / \mathrm{kg}$ of BW + sucrose. Group IV was white leadtree extract $3.5 \mathrm{~g} / \mathrm{kg}$ of BW + sucrose. Group V was white leadtree extract $7.8 \mathrm{~g} / \mathrm{kg}$ of BW + sucrose, all of them had similar effect as the acarbose positive control group. Furthermore, acarbose, $0.5 \%$ $\mathrm{CMC}$, white leadtree extract was administered orally using rat oral gavage.

Dosage of intervention. The extract dosage was determined based on previous research by Silvita et al. (2015), which stated that the infusion of white leadtree at dose of $2.1 \mathrm{~g} / 200 \mathrm{~g}$ of BW, $3.5 \mathrm{~g} / \mathrm{kg}$ of BW, and $7.8 \mathrm{~g} / \mathrm{kg}$ of BW had a postprandial antihyperglycemic effects.

Acarbose as positive control was a hypoglycemic drugs used as diabetic therapy (Ndraha 2014). Acarbose was a type of diabetic drugs as an inhibitor of alpha glycosidase enzyme to present postprandial hyperglycemia. Acarbose binds to $\alpha$-glucosidase enzyme in gastrointestinal tract, so disaccharide hydrolysis in small instestine is disrupted. This reduces the possibility of glucose absorption in the digestive tract to go into blood. Acarbose is used relatively often in diabetes treatment, its mechanism was similar to the antidiabetic effect of white leadtree (Manaf 2010). The used of acarbose in those who had glucose tolerance disorder was not only associated to $36 \%$ reduction of diabetes risk development, but also might reduce the risk of developing new cases of hypertension by $34 \%$ and reduce the risk of cardiovascular occurrence, especially silent myocardial infarction by $49 \%$ (Ceriello et al. 2006). Acarbose therapy dosage used in this study was $50 \mathrm{mg}$ (Willihnganz 2013). Furthermore, that dosage was converted based on Laurance and Bacharach table. Dosage of a $70 \mathrm{~kg}$ human to $200 \mathrm{~g}$ mice is equivalent to 0.018 times of human dosage. The calculation of the acarbose dosage used in this study was $50 \mathrm{mg} \times 0.018=0.9$ $\mathrm{mg} / 200 \mathrm{~g}$ of BW.

Meanwhile, $0.5 \% \mathrm{CMC}$ was used as the negative control. Kristanto and Christofer (2015) described that $0.5 \% \mathrm{CMC}$ was a thickener, emulsion stabilizer, and neutral, so it did not contain any substance that could produce hypoglycemia. The dose of sucrose used in all groups was $2 \mathrm{~g} / \mathrm{kg}$ of BW=0.4 g/200g of BW of mice (Parmawati 2014).

Alloxan dosage used was $125 \mathrm{mg} / \mathrm{kg}$ of $\mathrm{BW}$. The dosage selection was based on the results of initial research that had been done previously and had ensured that alloxan at a dose of $125 \mathrm{mg} /$ $\mathrm{kg}$ of BW might cause pancreatic damage, but not death (Sulistyaini 2015).

\section{Data analysis}

Data were presented in mean and SD. The concentration difference between Fasting Blood Glucose Diabetes Mellitus (FBGDM) and 2 Hour Post-Prandial Blood Glucose (2HPBG) was analyzed using one-way ANOVA and followed by Bonferroni post hoc test. Data processing and analysis were carried out using SPSS 2007 version 17 program. Statistical difference was considered significant if $\mathrm{p}<0.05$. 


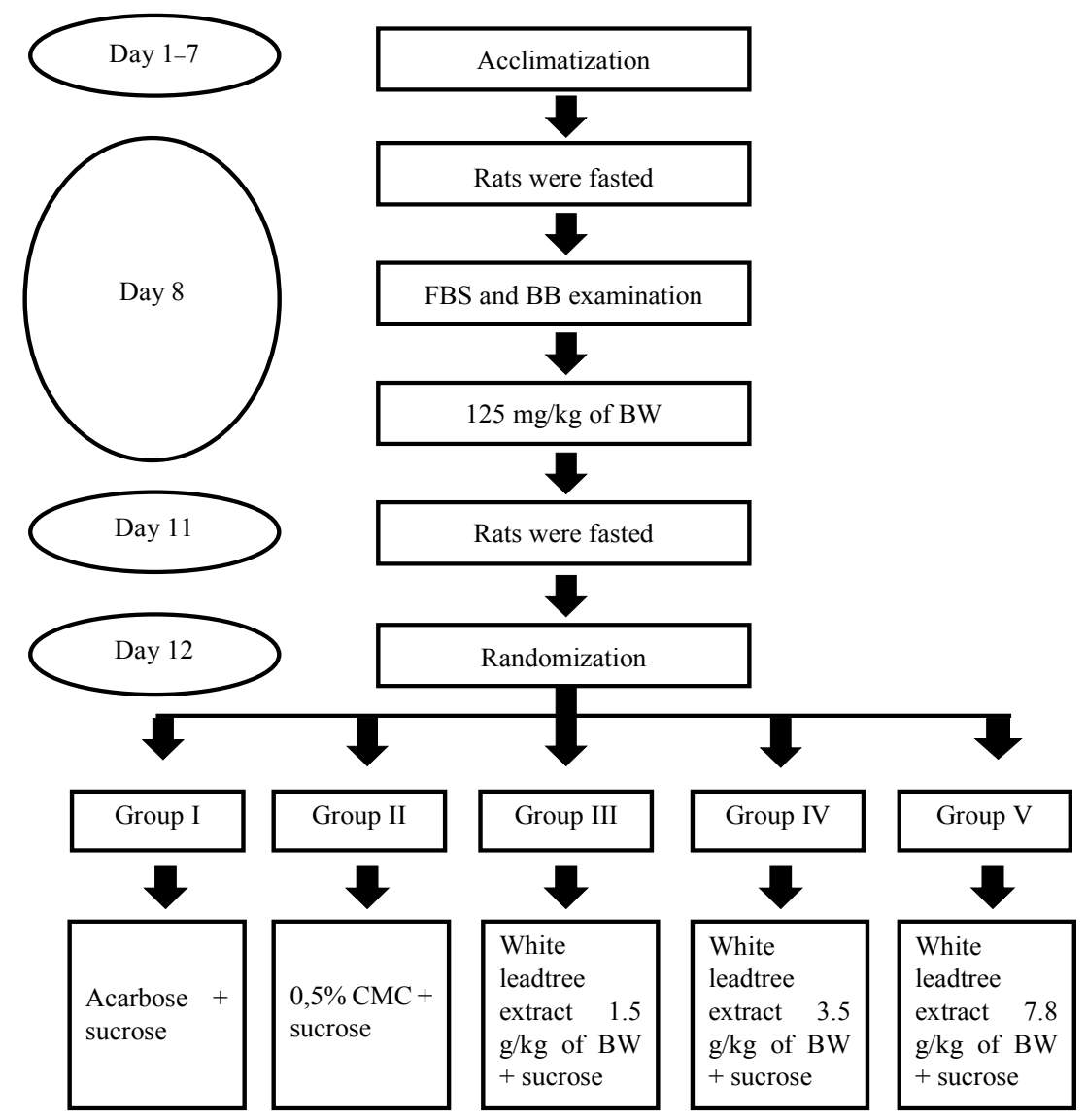

Figure 1. Study procedure

\section{RESULTS AND DISCUSSION}

Table 1 showed the average FBGDM concentration increased in all groups after administration of alloxan. The average $2 \mathrm{HPBG}$ concentration decreased in all groups after treatment. The highest difference between FBGDM and 2HPBG was in group V, 190.6 $\pm 8.792 \mathrm{mg} / \mathrm{dl}$.

The One Way ANOVA test result in Table 2 showed that there was a statistically significant difference between groups $(p<0.05)$. Therefore, Bonferroni post hoc test was conducted to investigate the significance value between groups.

The result of Bonferroni Post Hoc in Table 3 showed a significant value greater than 0.05 between positive control group (acarbose) and the group treated with white leadtree extract $1.5 \mathrm{~g} / \mathrm{kg}$ of BW, $3.5 \mathrm{~g} / \mathrm{kg}$ of BW, and $7.8 \mathrm{~g} / \mathrm{kg}$ of BW, so it could be concluded that there was no significant difference between positive control group and other three groups treated with white leadtree extract. The difference between the negative control group $(0.5 \% \mathrm{CMC})$, positive control group, and with white leadtree, however, showed a significant value less than $0.05(\mathrm{p}<0.05)$, which could be concluded that there was a significantly difference between negative group, positive control group, and three groups treated with white leadtree extract.

Material used in this study was $70 \%$ ethanol extract of whiteleadtree(Leucaenaleucocephala). It was used because the active compound in it had been separated from the plants' inactive or inert compounds by solvents, which were used during the extraction process. The purpose of this extract was to achieve maximum therapeutic effect since only active compounds were contained in it (Parmawati 2014). Ethanol was used because of its polar and inert properties. Polar solvent was able to break cells so the compounds in cells could be obtained. Inert properties played role in preventing decomposition (Shofiyullah 2015). The used of ethyl acetate fraction derived from white leadtree $70 \%$ ethanol has been proven to reduce blood glucose concentration in wistar rats induced by alloxan (Chahyono et al. 2012). White leadtree was used in this study because it is correspondent with the result of previous 
Table 1. Blood glucose concentration in pre-treated and post-treated mice (mg/dl)

\begin{tabular}{lcccc}
\hline \multirow{2}{*}{ Treated Groups } & \multicolumn{2}{c}{ Pre-treated } & Post-treated & \multirow{2}{*}{$\begin{array}{c}\text { FBGDM and } \\
\text { 2HPBG }\end{array}$} \\
\cline { 2 - 4 } & NFBG & FBGDM & 2HPBG & \\
\cline { 2 - 4 } Group I & $94.8 \pm 6.535$ & $283.8 \pm 24.904$ & $99.2 \pm 13.217$ & $184.6 \pm 17.530$ \\
Group II & $103 \pm 2.550$ & $286 \pm 21.436$ & $181 \pm 10.320$ & $105 \pm 11.402$ \\
Group III & $93.4 \pm 6.148$ & $278.8 \pm 13.103$ & $108.2 \pm 11.632$ & $170.6 \pm 17.981$ \\
Group IV & $73.8 \pm 7.727$ & $283.4 \pm 45.523$ & $106.2 \pm 9.884$ & $177.2 \pm 47.715$ \\
Group V & $81 \pm 17.507$ & $293.6 \pm 13.722$ & $103 \pm 11.009$ & $190.6 \pm 8.792$ \\
\hline NFBG: & Mean & Mean \pm SD & Mean \pm SD & \\
\hline
\end{tabular}

NFBG: Normal Fasting Bloog Glucose; FBGDM: Fasting Blood Glucose Diabetes Mellitus; 2HPBG: 2 Hour Post Prandial Blood Glucose; SD: Standard Deviation; $\Delta$ : Differences Group I: Positive Control (Acarbose); Group II: Negative control $(0.5 \%$ CMC); Group III: White leadtree extract $1.5 \mathrm{~g} / \mathrm{kg}$ of BW; Group IV: White leadtree extract $3.5 \mathrm{~g} / \mathrm{kg}$ of BW; Group V: White leadtree extract $7.8 \mathrm{~g} / \mathrm{kg}$ of BW

study, which stated that white leadtree contains flavonoids, tannins, and galactomannans, which are able to inhibit the increasing of blood glucose concentration by inhibiting $\alpha$-glucosidase activity. Alpha glucoidase played role in glucose absorption process in brush border cell membrane in small intestine (Silvita et al. 2015).

Based on Table 1, laboratory study showed that blood glucose concentration between pretreated group (FBGDM) and post-treated group (2HPBG) was decreased in all groups. The decreased of blood glucose concentration was due to incretin effect in small intestine. The incretin effect was played by two main hormones, Glucagon-like polypeptide-1 (GLP-1) and Glucose-dependent insulinotropic polypeptide (GIP) or gastric inhibitory polypeptide. Incretin hormones were then broken by the present of Dipeptidyl Peptidase-4 (DPP-4) enzymes, so they only worked for a few minutes (Balitbangkes 2013). GIP and GLP-1 were secreted from intestines during the sucrose consumption to stimulate secretion of insulin from pancreas $\beta$-cell. GIP and GLP-1 can give incretin effect by binding to their specific receptor, GIP Receptor (GIPR) and GLP-1 Receptor (GLP-1R). Receptor binding activated and increased intracellular cyclic adenosine monophosphate in pancreas cell so it could stimulate insulin secretion (Yutaka et al. 2010). In addition to stimulating the insulin secretion, GLP-1 also contributes in decreasing glucose by inhibiting glucagon secretion, slowing the gastric emptying time, and inducing the feeling of fullness (Aravind et al. 2015). Laboratory study result showed that the average blood glucose concentration differences between FBGDM and 2HPBG in negative control groups $(105 \pm 11.402 \mathrm{mg} / \mathrm{dl})$ was lower than in the control groups treated with white leadtree extract $1.5 \mathrm{~g} / \mathrm{kg}$ of BW $(170.6 \pm 17.981 \mathrm{mg} / \mathrm{dl}), 3.5 \mathrm{~g} / \mathrm{kg}$ of BW $(177.2 \pm 47.715 \mathrm{mg} / \mathrm{dl}), 7.8 \mathrm{~g} / \mathrm{kg}$ of BW $(190.6 \pm 8.792 \mathrm{mg} / \mathrm{dl})$ and positive control group $(184.6 \pm 17.530 \mathrm{mg} / \mathrm{dl})$. Rats in negative control groups experienced lower inhibition response in increasing blood glucose concentration compared to three groups treated with white leadtree extract and positive control group. Based on the data, it can be concluded that the groups treated with white leadtree extract and positive control group experienced a hypoglycemic effect, since the treatments were better in inhibiting the increase of blood glucose concentration compared to the negative control.

The result of one-way ANOVA test showed that there was a significant change in average blood glucose concentration between groups. The data analysis followed was continued with Bonferroni post hoc to investigate the significance between groups. The result of Bonferroni post hoc analysis showed a significant difference between negative control group with positive control group and all three groups treated with white leadtree extract $(\mathrm{p}<0.05)$. The result of Bonferroni post hoc test analysis also showed that there was no significant difference between positive control group and three groups

Table 2. Change in blood glucose concentration

\begin{tabular}{lccccc}
\hline & Sum of squares & df & Mean square & F & Sig. \\
\hline Between groups & 23833.360 & 4 & 5958.340 & 9.565 & .000 \\
Within groups & 12458.400 & 20 & 622.920 & & \\
Total & 36291.760 & 24 & & & \\
\hline One-way ANOVA test, significant at $\mathrm{p}<0.005$ & & & &
\end{tabular}

One-way ANOVA test, significant at $\mathrm{p}<0.005$ 
Table 3. Post hoc comparisons between control group and the group treated with white leadtree extract

\begin{tabular}{clc}
\hline Groups & \multicolumn{1}{c}{ Groups } & Sig. \\
\hline Positive control & Negative control & $0.001^{*}$ \\
& $1.5 \mathrm{~g} / \mathrm{kg}$ of BW & 1.000 \\
& $3.5 \mathrm{~g} / \mathrm{kg}$ of BW & 1.000 \\
& $7.8 \mathrm{~g} / \mathrm{kg}$ of BW & 1.000 \\
Negative control & Positive control & $0.001^{*}$ \\
& $1.5 \mathrm{~g} / \mathrm{kg}$ of BW & $0.001^{*}$ \\
& $3.5 \mathrm{~g} / \mathrm{kg}$ of BW & $0.002^{*}$ \\
& $7.8 \mathrm{~g} / \mathrm{kg}$ of BW & $0.000^{*}$ \\
$1.5 \mathrm{~g} / \mathrm{kg}$ of BW & Positive control & 1.000 \\
& $\mathrm{Negative} \mathrm{control}$ & $0.001^{*}$ \\
& $3.5 \mathrm{~g} / \mathrm{kg}$ of BW & 1.000 \\
& $7.8 \mathrm{~g} / \mathrm{kg}$ of BW & 1.000 \\
$3.5 \mathrm{~g} / \mathrm{kg}$ of BW & Positive control & 1.000 \\
& Negative control & $0.002^{*}$ \\
& $1.5 \mathrm{~g} / \mathrm{kg}$ of BW & 1.000 \\
& $7.8 \mathrm{~g} / \mathrm{kg}$ of BW & 1.000 \\
& Positive control & 1.000 \\
& Negative control & $0.000^{*}$ \\
& $1.5 \mathrm{~g} / \mathrm{kg}$ of BW & 1.000 \\
& $3.5 \mathrm{~g} / \mathrm{kg}$ of BW & 1.000 \\
\hline
\end{tabular}

treated with white leadtree extract $(\mathrm{p}>0.05)$. This might happen because white leadtree contains hypoglycemic active compounds, such as flavonoids, tannins, and galactomanans that inhibit $\alpha$-glucosidase enzymes so the glucose absorption in intestinal brush border membrane was disrupted. In addition, tannin contained in white leadtree can induce the regeneration of pancreatic $\beta$-cells. Furthermore, flavonoid compounds in white leadtree in the form of isoflavones could act as antioxidant, which plays a role in inhibiting the damage that might occur in Langerhans islets of the pancreatic $\beta$-cells (Suryanti et al. 2016).

The results of this study were parallel with the study by Silvita et al. (2015), which described that white leadtree infusion inhibited the increasing of postprandial blood glucose concentration in diabetic mice model, and parallel with the study conducted by Nugraha and Yusuf (2015), which stated that white leadtree extract was effective in reducing the blood glucose concentration in hyperglycemic rats induced by alloxan, marked with changes in Langerhans islets diameter size and the number of the $\beta$-cells.

\section{CONCLUSION}

The three white leadtree extract dosages were able to inhibit the increase of the two-hour postpandrial blood glucose concentration. There was no significant statistical difference between the positive control of acarbose treatment and the groups of white leadtree treatments of $7.8 \mathrm{~g} /$ $\mathrm{kg}$ of BW, $1.5 \mathrm{~g} / \mathrm{kg}$ of BW and $3.5 \mathrm{~g} / \mathrm{kg}$ of BW. However, the white leadtree extract of $7.8 \mathrm{~g} / \mathrm{kg}$ of BW showed the best inhibition effect. This result was due to mixed effect of several active compounds in the white leadtree extract, which cause a synergistic effects.

\section{ACKNOWLEDGEMENT}

The authors would like to thank all the parties who had helped and participate in this study. The authors has no conflict of interest.

\section{REFERENCES}

Akrom, Harjanti PD, Armansyah T. 2014. Efek hipoglikemik ekstrak etanol umbi ketela rambat (Ipomoea batatas P) (EEUKR) pada mencit swiss yang diinduksi aloksan. Pharmaçiana 4(1):65-76.

Aravind SR, Saboo B, Sadikot S, Shah SN, Makkar BM, Kalra S, Kannampilly J, Kesavadev J, Ghoshal S, Zargar AH, et al. 2015. Consensus statement on management of post-prandial hyperglycemia in clinical practice in India. J Assoc Physicians India 63:45-58.

[Balitbangkes] Badan Penelitian dan Pengembangan Kesehatan. 2013. Riset Kesehatan Dasar. Jakarta: Kemenkes RI.

Ceriello A. 2005. Perspectives in diabetes postprandial hyperglycemia and diabetes complications: Is it time to treat?. Diabetes 54(1):1-7. https://doi.org/10.2337/diab etes.54.1.1

Ceriello A, Davidson J, Hanefeld M, Leiter L, Monnier L, Owens D, Tajima N, Tuomilehto J. 2006. Postprandial hyperglycaemia and cardiovascular complications of diabetes: An update. Nutr Metab Cardiovasc Dis 16(7):453-456. doi.org/10 .1016/j.numecd.2006.05.006.

Chahyono TB, Maulani A, Ridwan M, Syarifah AN, Adekayanti A, Widada H. 2012. Antidiabetic Drug Ethyl Acetate Fraction of Leucaena Leucocephala Seed Extract In Wistar Aloxan Induced. International 
Conference: Research and Application on Traditional Complementary and Alternative Medicine in Health Care (TCAM) (page 181-186), 22-23 June. Surakarta: Indonesia.

[Depkes RI] Departemen Kesehatan Republik Indonesia. 2013. Diabetes mellitus penyebab kematian nomor 6 di dunia: Kemenkes tawarkan solusi cerdik melalui posbindu. Departemen Kesehatan Republik Indonesia. http://www.depkes. go.id/article/view/2383/diabetes-melituspenyebab-kematian-nomor-6-di-duniakemenkes-tawarkan-solusi-cerdikmelalui-posbindu.html [Acessed 9 May 2017]

Derosa G, Maffioli P. 2012. $\alpha$-glucosidase inhibitors and their use in clinical practice. https://www.ncbi.nlm.nih.gov/pmc/ articles/PMC3506243/ [Acessed 7 March 2017].

Dijk JWV, Manders RJF, Hartgens F, Stehouwer CD, Praet SFE, Loon LJCV. 2011. Postprandial hyperglycemia is highly prevalent throughout the day in type 2 diabetes patients. Diabetes Res Clin Pract 93(1):31-37. https://doi.org/10.1016/j.dia bres.2011.03.021

Efendi R, Damayanthi E, Kustiyah L, Kusomorini N. 2010. Pengendalian kadar glukosa darah oleh teh hijau dan atau teh daun murbei pada tikus diabetes. J Gizi Pangan $5(2): 87-94$.

Febrian T. 2017. Uji Efektivitas Kulit Buah Naga Merah (Hylocereus polyrhizus) untuk Menghambat Pembentukan Asam Urat pada Tikus Puth Jantan Galur Sprague-Dawley yang Diinduksi Kafein [undergraduate thesis]. Jakarta: Universitas Pembangunan Nasional Veteran Jakarta.

Fonseca V.2003. Clinical significance of targeting postprandial and fasting hyperglycemia in managing type 2 diabetes mellitus. Curr Med Res Opin19(7):635-631.

[IDF] International Diabetes Federation. 2011. Diabetes Atlas. 5th Ed. Brussels (BE): International Diabetes Federation.

Jasaputra DK, Rahardja F, Christian E. 2014. Efek jus gel lidah buaya (Aloe vera L.) dalam menghambat penyerapan glukosa di saluran cerna pada manusia. Global Medical and Health Communication 2(1):1-5.

Kuppusamy UR, Arumugam B, Azaman N, Chai JW. 2014. Leucaena leucocephala fruit aqueous extract stimulates adipogenesis, lipolysis, and glucose uptake in primary rat adipocytes. Scientific World Journal 2014:1-8. http://dx.doi.org/10.1155/2014/ 737263

Kristanto H, Santoso MCKP. 2015. Prarencana pabrik na-cmc berbahan baku kulit singkong kapasitas na-cmc 5.921 ton/ tahun [Undergraduate Thesis]. Surabaya: Universitas Katolik Widya Mandala.

Manaf A. 2010. Targeting postprandial hyperglycaemia: Evidence for cardio vascular benefits with acarbose intervention. Sub bagian Metabolik Endokrin Bagian Ilmu Penyakit Dalam Fakultas Kedokteran Universitas Andalas. http://repository.unand.ac.id/86/1/ Targeting_Postprandial_Hyperglycaemia. pdf.

Ndraha, S. 2014. Diabetes Melitus tipe 2 dan tatalaksana terkini. Medicinus 27(2):9-16.

Node K, Inoue T. 2009. Postprandial hyperglycemia as an etiological factor in vascular failure. Cardiovasc Diabetol 8(23):1-10.

Nugraha DR, Yusuf AL. 2015. Efek antihiperglikemik ekstrak etanol dan ekstrak heksan biji petai cina (Leucaena glauca, Benth) pada tikus putih jantan diabetes yang diinduksi aloksan 2(1):110. https://docplayer.info/44924250-Efekantihiperglikemik-ektsrak-etanol-danekstrak-heksan-biji-petai-cina.html.

Parmawati RRPI. 2014. Efek ekstrak etanol pohon ciplukan (Physalis angulata L) terhadap penurunan konsentrasi gula darah tikus jantan galur wistar yang diinduksi dengan aloksan tetrahidrat [Skripsi]. Jakarta: Universitas Pembangunan Nasional Veteran Jakarta.

Seino Y, Fukushima M, Yabe D. 2010. GIP and GLP-1 the two incretin hormones: similarities and differences. J Diabetes Investig 1(1-2):8-23.

Shofiyullah M. 2015. Identifikasi senyawa aktif dan uji potensi antimalaria ekstrak etanol $80 \%$ batang widuri (Calotropis gigantea) pada hewan coba yang terinfeksi Plasmodium berghei [Undegraduate Thesis]. Malang: UIN Maulana Malik Ibrahim.

Silvita SD, Sastramihardja SH, Rukanta D. 2015. Efek Pemberian Infusa Biji Petai China (Leucaena leucocephala) dalam Menurunkan Konsentrasi Glukosa Darah Puasa Pada Mencit Model Diabet. 
Prosiding Penelitian Sivitas Akademika Unisba (Kesehatan) (page 955-961), Gelombang 2 Tahun Akademik 2014-2015. Bandung: Universitas Islam Bandung.

Suryanti AP, Artawan IK, Martriani NAT. 2016. Potensi Ektrak Kasar Biji Lamtoro Gung (Leucaena leucocephala) Untuk Menurunkan Glukosa Darah Tikus Putih. Prosiding Seminar Nasional MIPA 2016 (page 287-295), 30th July Bali: FMIPA Undiksha.

Utami M, Wowor MP, Mambo C. 2015. Uji efek pemberian ekstrak biji petai cina (Leucaena leucocephala L) terhadap konsentrasi gula darah tikus wistar (Rattus norvegicus) yang diinduksi aloksan. Jurnal e-Biomedik 3(1):363-367.

Willihnganz C. 2013. Basic Pharmacology for Nurses. Sixteen Edition. Canada: Elsevier. [WHO] World Health Organization. 2016. Diabetes. http://www.who.int/mediacentre factsheets/fs312/en/ [Acessed 18 September 2016].

Yuriska A. 2009. Efek aloksan terhadap konsentrasi glukosa darah tikus wistar [Undergraduated Thesis]. Semarang: Universitas Diponegoro. 